\section{Visual Culture, Disciplinary Engagement and Drawing Pedagogical Possibilities for an Indian Way of Architectural Thinking}

"The high technical polish which is the hallmark of the standard Hol-
Iywood product, would be impossible to achieve under existing Indian
conditions. What the Indian cinema needs today is not more gloss, but
more imagination, more integrity, and a more intelligent apprecia-tion
of the limitations of the medium. What our cinema needs above
everything else is a style, an idiom, a sort of iconography of cinema,
which would be uniquely and recognisably Indian."

Satyajit Ray in 'What is wrong with Indian Films?'
Architectural thinking and design process have always been dependent upon the representational medium and language of architecture - conventional drawings, diagramming, models, and iconography, to name a few. As a result of technological advancement (therefore possibilities) and socio-economic change, representation techniques have evolved, from conventional processes to 'augmented reality'. Representation techniques and means in the production of architecture are critical to cover the conceptual range in which architecture can be created. This paper places this issue within the larger heterogeneous culture comprising technological, social, economic aspects and aims to unravel the conceptual underpinnings of the existing architectural thinking, representational culture in India. It examines 'drawing' as a convincing and disciplinary medium of language and representation and steers towards a 'representational maxim' between technology and value, discipline and consumption, tradition and modernity in the context of architectural thinking process in India.

The forces of capitalism, globalization, consumer culture, celebrity and media culture, visual culture, technocracy have been instrumental in creating reality-based representational systems, which are reluctant to engage with the discipline of architecture and think beyond it. Steenson" ${ }^{1}$ remarks about Augmented Reality "A novel form of spatial representation, which substitutes for the actual experience". With access to augmented reality technology, the client no longer has to interpret the traditional plans, section and elevations, nor look into printed photomontage or virtual walkthroughs. He will be able to stand in his yet to come living room, go, on foot, from there to the kitchen, visit the bedrooms and, by doing so, get an 'augmented' experience of those spaces. Software is the agent of consumption, and it is only in the architectural process (thinking \& delving), that this consumptive culture subsides, notwithstanding the fact that, for many architects and students, software and technology are steadily and consciously becoming 'ends' rather than 'means' in the design process.

Rahul Mehrotra ${ }^{2}$ in his seminal work on contemporary India architecture, notes that capital on account of its impatience, creates architecture that is often whimsical, mostly vendor driven for enhancing speed of construction, with new roles emerging for architects who then interface with technology but also exchange and access information in a renewed relationship, with most patrons, which is largely based on and invested in Capitalism and Globalization. This concern is shared by Jaimini Mehta ${ }^{3}$ as well, who says "this is what is meant by the term 'end of ideology', I suppose". It seems it is in the nature of industrialized society to detach itself from ideology and present itself as a rational, empirical, and efficient system of economic functions.

1 Steenson, M., 2012. Computing, Computer-Aided Design, Media. Architectural School-Three Centuries of Educating Architects in North America, pp.

266-269.

2 Mehrotra, R., 2011. Architecture In India Since 1990. Mumbai: Pictor

Publishing Pvt Ltd

3 Mehta, J., 2001. Towards a New Pedagogy, New Delhi: Architexturez

Imprints.

\section{Sourav Banerjea}

Ansal University, India 
If 'meaning' is critical to architectural thinking and production, then how much is the design conception process pertinent? What are the possible methods in the realm of architecture that will create a 'culture of thinking'? If drawing is to be at all endorsed as that method, or at least the means, then one needs to understand how it falls prey to the superficial visual culture and gradually escapes the discipline of architecture and aligns itself with consumer capitalism? The question is then what can be the 'meaningful' method of Architectural Thinking in India?

Romaldo Giurgola once said "All great architecture of the past came to be, as a result of a desire to make good architecture first and foremost. They are the places where aesthetics and ethics were inextricably joined in the same practical system which provided the basis both for the construction of buildings and the creation of a work of art". A strong sense of 'architect-ness' is primal - it first needs to be inculcated innovatively in architecture institutions among students such that they can carry it as an indispensable value into the practice. The ideation and representation process becomes pivotal to address the current issues and priorities we face in India and to imbibe the uncharted wealth of traditional knowledge and wisdom of the subcontinent. In all plausible probability, therein lies the answer to our architectural ethics and aesthetics.

\section{EPISODE 1: POST-MODERN SOCIETY, ARCHITECTURAL THINKING AND REPRESENTATION}

The origins of post-modernisms across disciplines, says Frederic Jameson ${ }^{4}$, emerged as a specific reaction against the dominance of high modernism which had occupied the centre-stage of culture and academia, until the 1950s. The erosion of older distinctions between high culture and popular culture is another significant shift in the postmodern understanding of knowledge and disciplines. The emergence of postmodernism is closely related to the emergence of late consumer capitalism and its formal features express the deeper logic of consumer capitalism. It is interesting to note the consequences of consumer capitalism, on the disappearance of a sense of history, the way by which our entire contemporary social system has little by little begun to lose its capacity to retain its own past, has begun to live in a perpetual present and in a perpetual change that obliterates traditions of the kind which all earlier social information had, in one way or another, the intent to preserve.

The concept of representation, language and culture can be interlinked in the scholarly work of Stuart Hall ${ }^{5}$; where he explains representation as one of the central practices and a key moment in the circuit of culture which consists of identity, production, consumption and regulation. Hall further explains that culture is about 'shared meanings'; the production and exchange of meaning occurring through 'language' - the privileged medium in which we make sense 4 Jameson, F., 1998. Postmodernism and Consumer Society. In: The Cultural Turn: Selected Writings on the Postmodern, 1983-1998 (Radical Thinkers). S.1-20 ed. London: Verso, pp. 1-20.

5 Hall, S., 1997. The Work of representation. In: Representation: Cultural representation and signifying practices. Milton Keynes : SAGE Publications, pp. 13-75. of things. But language operates on 'representational system' - the use of signs and symbols - sounds, written words, musical notes, even objects - to represent ideas, concepts and feelings. Representation therefore becomes central to the process by which meaning is produced, and consequently how shared meanings give way to creation of culture. This concept is substantially applicable within the production of drawings and the drawing culture, in the realm of architectural thinking and discourse.

\section{ARCHITECTURAL THINKING AND REPRESENTATION}

The procedures on architectural design, appears to have shifted from drawing to the diagram, over the second half of the twentieth century (Somol, 2007) ${ }^{6}$. That does not mean that the diagram is the only form of architectural design or that diagrams were not used on the process of architectural design earlier. What it means is, in the last thirty years, the diagram has became an important tool in the thinking process. According to Bun ${ }^{7}$, in contemporary practice the design methods itself have gained extreme significance, which means that the theory that revolves around diagrams as a source of architectural design process have improved their way of seeing diagrams. Within this context, it is reasonable to say that diagrams are no longer pure geometry or structure, but an embodiment of all the meanings that underline its essence.

The utopian dreams of the 1960s and '70s avant-garde architecture movements wouldn't had been possible without the new forms of representation used by architects like Colin Rowe, John Hejduk and Peter Eisenman where the reader was in the position to decipher the (textual) message behind the represented work. Drawings, collages and cardboard models transmitted an urgency to be understood, to find consumers who are able to receive the message that was being sent. It is important to understand the significance of the representative process as a counterpoint to the materiality in built architecture; a propensity to regard immeasurable flow of imagination and thinking that lies in the process itself.

In the Indian context, any discussion on globalization and architecture needs to take into account the immense heterogeneity of the country. Not only are its physical and economic conditions diverse, but also people in the various layers of society live radically different lives and, consequently, have sharply divergent world-views. Indeed, this provoked A.K. Ramanujan ${ }^{8}$ to speculate: 'Is there an Indian way of thinking?' Architecture and education are not free from worldly affiliations and they have been the entry points for economic and cultural hegemony. Thus, it is essential to address three Indian architectural issues: first, relating to sustainability in both the ecological and human systems under conditions of poverty and scarcity of resources; second, the objective of the conservation of built and natural heritages both of which are being degraded at an alarming rate; and third, how to deal with emerging technologies and their implications 6 Somol, R. E., 2007. Dummy Text, or The Diagrammatic Basis. [Online] 7 Bun, Z., 2008. Between Analogue and Digital Diagrams. Enquiry: A Journal for Architectural Research, Vol. 5, 510.

8 Ramanujan, A., 1989. Is there an Indian Way of Thinking? An Informal Essay. In: Contributions to Indian Sociology. New Delhi/Newbury Park/London: SAGE Social Science Collections, pp. 1-23. 
for architectural design and education. The third one will determine whether technologies force the adoption of unsustainable and inappropriate ways of building or respond to the vast range of local conditions. (Menon, 2000) 9

Charles Correa ${ }^{10}$ intelligibly explains architecture as an amalgamation of four distinct attributes - climate, aspirations, culture $\&$ technology and how these four diverse parameters give meaning and purpose to architecture and architectural thinking. This paper, in agreement to Correa's proposition, attempts to understand the various parameters that impact architectural thinking and its representation, and how do these interact with and within each other.

\section{EPISODE 2: TECHNOCRATIC CULTURE AND VALUE CENTRIC CULTURE}

\section{TECHNOLOGY CENTRIC PROCESS}

Consider a case of technocratic thinking where technological dominance overpowers architectural thinking and production. Naturally, the weight of cultural connotations and ideas doesn't get to hold much ground, with little space left for cultural variations and eclectic values to make a significant footprint in the thinking process. The very essence of the modern project (and as an extension, technocracy) is to also to establish human dominance over nature and its energy flows (Pathak, 1998) ${ }^{11}$. There is a marked shift from the traditional, syncretic understanding of climate-cultural-societal systems and therefore, the absence of an architectural thinking and response that would have explored this territory as a virtue of art and design. Instead we are left with, or more realistically, we start living within the folds of technological templates; a culture in which human conditions and needs are limited to computer programing and coding. Gradually, technology seeps into the fabric of 'culture'; ceasing to be discernible as a 'deviation', as an 'invasion' - manifesting itself in the fourth component of our architectural premise - 'aspirations'. Human aspirations are neither insulated from cultural ideals, nor are they isolated from lucrative ideals of technological and economic prosperity. Thus, aspiration becomes an interesting vantage point to make sense of this paradox.

\section{VALUE CENTRIC PROCESS}

Consider another case in which technology becomes a 'means', a part of the process, a quintessential function of the 'doing' and 'realising', and not the 'end' of the process. This allows for a more intimate interaction between man and architecture. In this approach, the emphasis is not to question the selection of technology from a set of available options, rather it is to question the 'construction of need'; the cultural 9 Menon, A. K., 2000. Transcultural Dialogue in Architectural Education. Hong Kong, International Conference of the Association of Collegiate Schools of Architecture.

10 Correa, C., 2010. A Place in the Shade: The New Landscape \& Other Essays. New Delhi: Penguin Books, India.

11 Pathak, A., 1998. Culture as an arena of struggle: Debates around tradition, modernity and revival. In: Indian Modernity: Contradictions, Paradoxes and Possibilities. New Delhi: Gyan Publishing House, pp. 157-191. process transforming the 'desirable' into the 'needful'. In this case, there is a larger philosophical or moral agenda which needs to be addressed. Is the manifestation of architecture to be considered as a tangible idea (displayed by technological supremacy of structures, materials, systems etc.) or as a more qualitative thread, an intangible aspect? Where is the soul and mind of architecture? And how does it make a difference to the society and its built environment?

Aspiration and Culture, both have to be understood either as the 'driver' or the 'driven' in the architectural thinking process. How does one respond to such dichotomies at an educational level, especially through pedagogical systems? One needs to acknowledge, that the seemingly technical nature of architecture is not value-free and ideologically neutral and the aesthetic criteria, far from being universal and pre-determinable, is culturally variable. A school of architecture will be abdicating its responsibility if it, in addition to technical proficiency, fails to introduce the young architects to the cultural milieu within which one has to function and the dialectical relationship between the forces of change and his/her own technical and aesthetic decisions. This is especially critical in a developing and changing society such as India where the super-structural symbols an architect creates, whether detached houses for families, places of work or worships or monuments, will tell about the chosen relationships between 'Man and Man', between 'Man and Society' and between 'Society and Nature'. (Mehta, 2001)

Mehta further enunciates that while science begins with ideas and concepts and, through technology, seeks to create objects and events (transformation of the physical environment), art seeks to project an idea (of order, unity, a society built on a different set of value) through the corporeal forms. In other words, 'thinking' and 'doing' have different relationship in science and in arts.

Another perspective in this context is presented by Zygmunt Bauman ${ }^{12}$ in his seminal work on 'Liquid Modernity', where he connects the famous phrase of 'melting the solids' coined by the communist manifesto, more than a century back. By this phrase then, they referred to the treatment which the self-confident and exuberant modern spirit awarded the society it found much too stagnant for its taste and much too resistant to shift and mould for its ambitions - since it was frozen in its habitual ways. If the 'spirit' was 'modern', it must determine reality by freeing it of its own history - and this could only be done by 'melting the solids'. That intention demanded for disavowing and dethroning the past, first and foremost 'traditions', the sediment and residue of the past in the present; it thereby called for the smashing of the protective armour forged of the beliefs and loyalties which allowed the solids to resist the 'liquefaction'. He carefully presents a social conspiracy which, through systemic processes and the

12 Bauman, Z., 2006 . Foreword : on being Light and Liquid. In: Liquid Modernity. Cambridge, U.K: Polity Press, pp. 1-16. 
freedom of choice and convenience, has shaped the contemporary world we live in, devoid of our own history.

\section{EPISODE 3: VISUAL CULTURE AND DISCIPLINARY CULTURE}

\section{DRAWING, REPRESENTATION AND DISCIPLINARY CULTURE}

In Architecture, drawings embody time as a continuum. The 'stone laying score' for the construction of the stone walls at the Thermal Baths at Vals, in Switzerland by Peter Zumthor, is about telling. The "regularly irregular" wall was not drawn in a realistic way to anticipate a future likeness, rather the process of laying out stones was cadenced by providing a dimensional rhythm within which a degree of improvisation was possible, thus not attempting to foretell a final image but rather guiding the stone masons' expert hands in the assembly of the wall. However, the photorealistic digital rendering of the contemporary architectural culture has reduced representation to a question of instantaneous perception. The still shots of architectural renderings have reduced architecture to skin-deep design lacking knowledge of construction (Goffi and Lepage, 2013)13.

Frank Lloyd Wright ${ }^{14}$ unfolded the drawing process in 'The Logic of the Plan', that influenced Kahn's growing understanding of the fundamentals of all great architecture - "A good plan is the beginning and the end. And its development in all directions is inherent - inevitable... There is more beauty in a fine ground plan than in almost any of its ultimate consequences. To judge the work of an Architect, one needs only to look at his ground plan. Because before the plan is a plan, it is a concept in some creative mind". Modernists believed in the absolute processes of establishing architecture, and often exhaustively used different formats of traditional drawings and representational techniques. Ideas connected to formal and axial systems, modular and grid based systems, minimalist functions, found pertinence in the works of the High Modernists.

Amongst the postmodernists, Peter Eisenman has been keen to explore linguistics of architecture through minimum notational elements as generators of form. In this sense, the drawing process evolves into a diagrammatic method that got consolidated in the search for an exemplary design process: as the object itself did not represent and communicate intentions, it was necessary to show the process. The procedures have a clear syntactic position, ignoring any attempt of representational meaning in architecture and do not claim a communicative status of architecture and his design process intended to be abstract, unrelated to any external references, free of contamination (Moneo, 2008) ${ }^{15}$.

Rem Koolhaas ${ }^{16}$, on the other hand, examines the representation of

13 Lepage, F. G. a. D., Goffi, F. \& Lepage, D., 2013. Drawing thinking: a lost currency?. Nottingham Trent University, UK, AAE CONFERENCE, SAGE Journals.

14 Wright, F. L., 1928. In the Cause of Architecture, I: The Logic of the Plan. The Architectural Record, pp. 49-57.

15 Moneo, R., 2004. Theoretical anxiety and design strategies in the work of eight contemporary architects. Cambridge Mass.: MIT press

16 Koolhaas, Rem. and Mau, Bruce. (1995). S, M, L, XL, New York: Monacelli the project in detail through new schemes of design: collages, selection of emblematic images and graphic notations that explore different layers of contents: programmatic indecisiveness, functional definition and finally, the formal aesthetic of the building. Koolhaas graphic schemes can be understood as hyper-active surfaces, which allows him to develop the design in an abstract and complex manner. For Koolhaas, iconography is the tool for the design process (Moneo, 2008).

\section{VISUAL CULTURE, SEXINESS \& CONSUMER CULTURE}

The 'notion' of sexiness, as also the 'fancy' of it, is quite symbolic of our visual consumer culture and is an exemplar of all the facets of our intellectual and aesthetic existence in the contemporary liquefied postmodern society. The idea of 'sexiness' deeply pervades the understanding and perception of representational means - especially the visually attractive 3D processes and produces. The question of 'how does it look' overshadows the quest of 'what does it mean'. The culture of creating split-second impacts, technology-intensive realistic imageries resonate well with the consumer society, reducing the manifold layers of architectural thinking to a single focal point. The spirit of drawing, in all its capacity, can address the gap between the discipline and the market, between significance and relevance, between radical experimentation and conventional reproduction.

Architecture in the West, at least since the advent of modernism, has focused on the avant-garde. The pursuit of the avant-garde dovetails with the imperatives of consumerism, first within the boundaries of a local market, and later spreads to dictate conditions in the global market (Menon, 1998) ${ }^{17}$. In quest of the avant-garde representation, the design process alludes to a culture of 'fashion', 'branding' and making of a celebrity culture. The architectural and spatial quality of the design is the last point of discussion, since the crux of mindspace gets occupied by the unusual, surreal forms and representations of pseudo-reality. This is specifically relevant and applicable to the contemporary Indian architectural scenario. This is not to deny the potential of 3D modelling and BIM software as fantastic means of realising ideas, but at the same time, the concern is to be critical of the situation where the discipline of architecture gets invaded heavily by consumer capitalism, uprooting the educational, professional ethics and moral arguments. Therefore an incessant cycle of 'mindless consumption' gets created in place of a 'culture of questioning'.

\section{EPISODE 4: ARCHITECTURAL SITUATION AND SEQUENTIAL PACE}

\section{APPRECIATION, PACE \& SLOWNESS}

The challenge of architecture today is to focus on architecture itself - drawings, models, architectural texts and buildings - as its locus of knowledge and, specifically, on how that knowledge can become a

\section{Press}

17 Menon, A. K., 1998. Architectural Education in India in the Time of Globalisation, Gazimagusa, North Cyprus: Eastern Mediterranean University 
tool of the design thinking process (Theory by Design Conference at Antwerp in 2012). Drawings, models and architectural texts support a building's conception and, inverse $\neg$ ly, buildings are the products to continuously reformulate those ideals. One needs to understand that studios in architectural institutions are not true replicas of design office studios. For the latter, drawings and models are just a fic $\rightarrow$ tion that represents and anticipates reality while buildings constitute reality, while on the other hand, for the former, the fictional studio design project, ideally represented through drawings and models, themselves becomes the reality of a subjective fiction.

We must shift from 'code abiding' to 'code making'; to conceive drawing as a form of material imagination capable of redefining itself over time. Umberto Eco explains this "involves a type of discourse which announces a possible code, which produces a new articulation of the culture" (Goffi and Lepage, 2013). The concerns of our discipline are predicated on rigorous appreciation and engagement with the subject in question. The quest for meaning becomes the visible, or at times the obscure goal of the disciplinary culture. This perusal of meaning is philosophically rooted in the idea of art and the artistic agenda. What happens when 'meaning' is replaced by 'purpose', which is then overlapped with 'role or function'? From there, it starts developing into an 'experiential idea' - giving way to experiential culture. The act and process of experience leans towards the 'populist idea' and draws heavily from an anarchical intellectual vacuum. As a result of which, the process lends itself to a consumptive experience, marked up as an approach of 'whole appreciation'. Pace and slowness become key drivers which draw a fine line between 'experiential movement across the whole' and 'disciplinary engagement with the part'. In this effect, Drawing as a representational medium, upholds the emphasis on meaning and understanding of 'part appreciation'. Non-drawing means of architectural thinking, owing to its inevitable object of experiential understanding, gravitate towards a consumptive relevance of the thinking process.

\section{CONCLUSION: PROSPECTS \& POSSIBILITIES OF 'DRAWING' AS REPRESENTATION}

\section{ARCHITECTURAL EDUCATION, INDIA \& THE WEST}

What can the West learn from India? For one, how to deal with deprivation and scarcity. The resources of this planet are finite and if India were to emulate the West as is being suggested by both multinational business interests and Western educational institutions, the consequences would be disastrous for everyone. For another, some of the finest cultural resources exist in India and the Third World as living traditions. The First World has lost much of its own through industrialization and wars and a similar prospect confronts the Third World. This will be a profound loss for the cultural diversity of our planet (Menon, 2000).

Architectural Education was traditionally the responsibility of master craftsmen and passed along from one generation to another. Learning through apprenticeship and through the modern institution of school are two very different propositions and the difference is often not understood. "This kind of double corporeality can either transform or not transform architecture. While part of it works to bring about reform, the other part keeps change at bay" (Toyo Ito, 2000). In architecture, this tension also relates to a disjoint between tradition and technology, as Reyner Banham ${ }^{18}$ observes, "architecture defined in terms of its professional history versus architecture as the provision of fit environments for present human activities". In the current discourse, let us conclude by enlisting the important roles of 'drawing as a representation tool', that are being obliterated from architectural thinking, so as to impede the disciplinary amnesia surrounding architectural representation.

\section{DRAWING AS AN 'EXPRESSION', AGAINST 'COMMUNICATION'}

The popular understanding of drawing as a language, or just as a means of communication needs to be questioned. It is imperative to move beyond such functional interpretation of drawing as the language of architectural thinking and representation. The act of drawing and its finer peculiarities need to be determined and get sensitised with; consider 'language' as the maker of literature, consider drawing as an 'expression'. When one can describe someone's drawings as "a presence in itself, a poetic impulse", as Germano Celant ${ }^{19}$ observes about Aldo Rossi's drawings, one can claim that the power of representation lies beyond materials and forms. Representation by means of lines aims to define our conception of space but then becomes a contradiction, when the poetry behind the representation surpasses those definitions and becomes the starting point for new thoughts, ideas and expressions. Pierre Francastel ${ }^{20}$ states that the artist invents while drawing and the particular technique that he uses, imposes always, a certain discriminatory order. Representation must be understood as a space for the construction of ideas, a provisional condition for a series of possible transformations. Architectural thinking, through the process of drawing needs to find a voice, an expressive lexicon to arrive at a meaning as well as to find a larger artistic and functional purpose in the Indian society.

\section{DRAWING AS 'MINIMALIST, NO-NONSENSE THINKING'}

In case of drawing becoming the means of representation of ideas, the cognitive differential between the simultaneous processes of thinking, manifesting and evaluating diminishes. Since every element of representation is corresponding to an idea wanting to be expressed, the process must become 'no-nonsense and minimal'. In the drawing culture, the analytical framing of the view and fixated point of vision nurtures objectivity in the translation and representation process. The means, underlays and overlays used as the ideation for drawing may be diverse and eclectic in terms of their conceptual and philosophical orientations, and yet the process is invariably noise-free by

18 Banham, R., 1960. Theory and Design in the First Machine Age, New York, Washington: PRAEGER PUBLISHERS. 19 Germano, Celant, G., Ghirardo, D. \& Molinari, L., 2008. Aldo Rossi Drawings. 2268th ed. Switzerland: Skira

20 Francastel, P., 2000. Art \& Technology in the Nineteenth and Twentieth Centuries. Cambridge, Massachusetts: Zone Books, The MIT Press 
virtue of its representational spirit. Because in this case, there is a lot of 'doing' going on - an attempt to simultaneously address diverse concerns; therefore, an effective, minimalist method escapes the ideation process and a fair quantum of 'supporting performers' or noise comes into the process, and consequently the product. As the architecture moves towards the crystallisation stage, these 'supporting performers' find reason and tenability and are no longer understood as 'supporting' owing to the very nature of the translation process and the way it consumes noise which can no longer be edited out.

A lot of questions and concerns surrounding drawing as a representational means will need to be addressed. If drawing is to be endorsed, then how to respond to the consumerist idea embedded in the visual culture? How does this embedded consumerism accentuate and augment the disciplinary obliviousness? How does it gradually escape the 'sphere of architecture'? On the other hand, what are the threats/concerns which make drawing an inward looking phenomenon, and how should it be dealt with? Is there a third way, an Indian Way of Architectural Thinking through drawing? Where should the core of Indian architectural philosophy and communication rest?

It would be conclusive to bring back Satyajit Ray's ${ }^{21}$ perspective - "avoid the gloss of western thinking, and bank more on our imaginative being and the appreciation of the Indian traditions". And as Wang Shu echoed, "If we lose our traditions, I believe that we have no future" (Wang Shu, 2012).

\section{Notes}

1. Banham, Reyner. 1960. Theory and Design in the First Machine Age. New York, Washington: PRAEGER PUBLISHERS.

2. Bauman, Zygmunt. 2006. "Foreword: on being Light and Liquid." In Liquid Modernity, 1-16. Cambridge, U.K: Polity Press.

3. Bun, Zoltan. 2012. "Between Analogue and Digital Diagrams." Enquiry: A Journal for Architectural Research, Vol. 5. https:// doi.org/10.17831/enq:arcc.v5i2.13.

4. Carreiro, M., P. Pinto. 2013. "The evolution of representation in architecture." www.http://papers. cumincad.org. http://papers.cumincad.org/data/works/att/ ecaade2013r_001.content.pdf.

5. Correa, Charles. 2010. A Place in the Shade: The New Landscape \& Other Essays. New Delhi: Penguin Books, India.

6. Francastel, Pierre. 2000. Art \& Technology in the Nineteenth and Twentieth Centuries. Cambridge, Massachusetts: Zone Books, The MIT Press.

7. Germano, Germano Celant, Diane Ghirardo, and Luca Molinari. 2008. Aldo Rossi Drawings. 2268th. Switzerland: Skira.

8. Hall, Stuart. 1997. "The Work of representation." In Representation: Cultural representation and signifying practices, 13-75. Milton Keynes: SAGE Publications.
9. Jameson, Fredric. 1998. "Postmodernism and Consumer Society." In The Cultural Turn: Selected Writings on the Postmodern, 1983-1998 (Radical Thinkers), 1-20. London: Verso.

10. Koolhaas, Rem. 2004. Content. Köln: Taschen.

11. Lepage, Federica Goffi and David, Federica Goffi, and David Lepage. 2013. "Drawing thinking: a lost currency?" Nottingham Trent University, UK: AAE CONFERENCE, SAGE Journals.

12. Mehrotra, Rahul. 2011. Architecture In India Since 1990. Mumbai: Pictor Publishing Pvt Ltd.

13. Mehta, Jaimini. 2001. Towards a New Pedagogy. New Delhi: Architexturez Imprints. Accessed September 22, 2018. https://architexturez.net/doc/az-cf-21236.

14. Menon, AG Krishna. 1998. Architectural Education in India in the Time of Globalisation. Gazimagusa, North Cyprus: Eastern Mediterranean University.

15. - . 2000. "Transcultural Dialogue in Architectural Education." Hong Kong: International Conference of the Association of Collegiate Schools of Architecture.

16. Moneo, Rafael. 2008. "Inquietação teórica e estratégia projetual na obra de oito arquitetos contemporâneos." Coleção Face Norte, volume 12 (Cosac Naify).

17. Pathak, Avijit. 1998. "Culture as an arena of struggle: Debates around tradition, modernity and revival." In Indian Modernity: Contradictions, Paradoxes and Possibilities, 157-191. New Delhi: Gyan Publishing House.

18. Ramanujan, A.K. 1989. "Is there an Indian Way of Thinking? An Informal Essay." In Contributions to Indian Sociology, 1-23. New Delhi/Newbury Park/London: SAGE Social Science Collections.

19. Ray, Sayajit. 2001. Our Films Their Films. New Delhi: Orient BlackSwan.

20. Somol, Robot E. 2007. Dummy Text, or The Diagrammatic Basis. <http://www.revistas.usp.br/ risco/article/.

21. Steenson, Molly. 2012. "Computing, Computer-Aided Design, Media." Architectural School-Three Centuries of Educating Architecs in North America 266-269.

22. Wright, Frank Lloyd. 1928. "In the Cause of Architecture, I: The Logic of the Plan." The Architectural Record 49-57.

21 Ray, S., 2001. Our Films Their Films. New Delhi: Orient BlackSwan 